\title{
Goiânia mil grau: dialogismo, heterodiscurso e carnavalização nos memes de internet
}

\author{
Goiânia mil grau: dialogism, heterodiscourse and carnivalization in internet \\ memes
}

\section{Goiânia mil grau: dialogismo, heterodiscurso y carnavalización en los memes de internet}

\author{
Luiz Felipe Fernandes Neves ${ }^{l}$ \\ Ricardo Pavan ${ }^{2}$
}

\begin{abstract}
Resumo
Este trabalho articula reflexões teóricas dos atuais estudos da Comunicação com categorias balizadoras do pensamento do russo Mikhail Bakhtin $(2002,2010,2011,2015,2016)$. Para isso, é analisado um fenômeno contemporâneo típico da chamada cibercultura: os memes de internet, constituídos por mensagens bem-humoradas e de estética amadora que circulam em sites de redes sociais e comunidades virtuais. Procura-se evidenciar, nesse tipo de mensagem, a essência de conceitos como dialogismo, heterodiscurso e carnavalização. Como proposta de operacionalização teórico-metodológica, é apresentada a análise de um vídeo paródico publicado na página de humor Goiânia Mil Grau, que abriga elementos discursivos que atuam na construção de sentidos sobre o que é ser goiano e goianiense.
\end{abstract}

Palavras-chave: Meme. Dialogismo. Heterodiscurso. Carnavalização.

\begin{abstract}
This paper articulates the theoretical reflections of the current studies of Communication with fundamental categories of the Russian Mikhail Bakhtin (2002, 2010, 2011, 2015, 2016). For this purpose, a contemporary phenomenon typical of the so-called cyberculture is analyzed: the internet memes, consisting of humorous messages with amateur aesthetics that circulate throughout social media and virtual communities. In this type of message, we highlight the essence of concepts such as dialogism, heterodiscourse and carnivalization. As a proposal for theoretical-methodological operationalization, the analysis of a parodic video published in Goiânia Mil Grau humor page is presented, which contain discursive elements that act in the construction of meanings about what is to be a person who born in the state of Goiás and in the city of Goiânia.
\end{abstract}

Keywords: Meme. Dialogism. Heterodiscourse. Carnivalization.

\section{Resumen}

Este trabajo articula reflexiones teóricas de los actuales estudios de la Comunicación con categorías balizadoras del pensamiento del ruso Mijaíl Bajtín (2002, 2010, 2011, 2015, 2016). Para eso, se analiza un fenómeno contemporáneo típico de la llamada cibercultura: los memes de internet, constituidos por mensajes bien humorados y de estética amadora que circulan en sitios de redes sociales y comunidades virtuales. Se busca evidenciar, en ese tipo de mensaje, la esencia de conceptos como dialogismo, heterodiscurso y carnavalización. Como propuesta de operacionalización teórico-metodológica, se presenta el análisis de un vídeo paródico publicado en la página de humor Goiânia Mil Grau, que alberga elementos discursivos que actúan en la construcción de sentidos sobre lo que es ser goiano y goianiense.

\footnotetext{
${ }^{1}$ Mestrando do Programa de Pós-Graduação em Comunicação da Universidade Federal de Goiás. e-mail: lffernandes08@gmail.com

${ }^{2}$ Doutor em Comunicação, docente do Programa de Pós-Graduação em Comunicação da Universidade Federal de Goiás. e-mail: pavan.ufg@gmail.com
}

Comun. \& Inf., Goiânia, GO, v. 21, n. 3, p. 150-165, out./dez. 2018. 
Palabras clave: Meme. Dialogismo. Heterodiscurso. Carnavalización.

\section{INTRODUÇÃO}

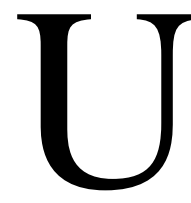

suários da internet, sobretudo de sites de rede social e integrantes de comunidades virtuais, estão familiarizados com um tipo característico de mensagem bem-humorada, geralmente constituída por montagens grosseiras, aspecto intencionalmente amador e conteúdo sucessivamente parodiado. Trata-se do meme, que, graças às possibilidades de fácil e rápido compartilhamento proporcionadas pelas ferramentas online, atinge um público numeroso e diverso, dando origem a fenômenos virais (SHIFMAN, 2014) ou eventos digitais (SOUZA JÚNIOR, 2015).

As áreas da Comunicação e da Linguística lideram a atual produção acadêmica brasileira que têm os memes de internet como objeto de pesquisa ${ }^{3}$. De uma forma geral, os estudos analisam a construção de sentidos operada por esse tipo de mensagem no contexto das novas tecnologias de informação e comunicação, relacionando essas análises a dimensões como a cultura, a política, os meios de comunicação, o marketing e até a aspectos ligados à história e à religião.

Este trabalho surge na esteira dessas investidas acadêmicas, com o objetivo de analisar como o meme de internet atua na constituição de tramas de significados, por meio de estratégias discursivas que deslocam as fronteiras do local e do global, valendo-se sobretudo da retórica do humor. Do ponto de vista teórico-metodológico, o artigo busca articular os estudos da Comunicação relacionados à chamada cibercultura (LEMOS, 2013; LÉVY, 2010) com o arcabouço epistemológico construído pelo pensador russo Mikhail Bakhtin (2002, 2010, 2011, 2015, 2016).

Para isso, o trabalho se divide em três partes. Na primeira, é apresentado um breve histórico sobre o conceito de meme, culminando em sua acepção contemporânea, como fenômeno dos ambientes digitais de comunicação. Também são abordadas as definições de cibercultura e ciberespaço. Na sequência, são delimitados alguns conceitos que emergem do pensamento de Bakhtin - como dialogismo, heterodiscurso e carnavalização -, paralelamente a um esforço de compreendê-los do ponto de vista dos memes de internet. Por último, é feita a

\footnotetext{
${ }^{3}$ A busca pelo termo meme e seus correlatos (memes, memético, memética) no Banco de Teses e Dissertações da Coordenação de Aperfeiçoamento de Pessoal de Nível Superior (Capes) resulta em 23 trabalhos que abordam esse objeto, sendo sete dissertações e uma tese na área da Comunicação e seis dissertações e uma tese na área de Letras e Linguística. Disponível em: <www.catalogodeteses.capes.gov.br〉. Acesso em: 10 jul. 2018.
}

Comun. \& Inf., Goiânia, GO, v. 21, n. 3, p. 150-165, out./dez. 2018. 
análise de um vídeo da página Goiânia Mil Grau, conhecida por utilizar memes em suas publicações e abordar, de forma bem-humorada, traços e hábitos que seriam característicos do estado de Goiás e de sua capital, Goiânia, assim como de sua população. A análise é realizada à luz das categorias bakhtinianas, na perspectiva aventada por Machado (2005), ao abordar a amplitude teórica deste pensador:

Graças a essa abertura conceitual é possível considerar as formações discursivas do amplo campo da comunicação mediada, seja aquela processada pelos meios de comunicação de massas ou das modernas mídias digitais, sobre o qual, evidentemente, Bakhtin nada disse, mas para o qual suas formulações convergem (MACHADO, 2005, p. 152).

Colocado em diálogo com os atuais estudos da Comunicação, espera-se que o desenvolvimento deste trabalho contribua para refletir sobre como as novas dinâmicas comunicacionais, a exemplo do meme de internet, ajudam a compreender os processos culturais em curso na contemporaneidade que muito dizem sobre nós e nossas relações.

\section{O MEME COMO FENÔMENO DA CIBERCULTURA}

Apesar do uso corrente entre usuários das redes sociais digitais, o termo meme não se originou nesse ambiente e nem sempre esteve associado a textos, fotos e vídeos bem-humorados disseminados pela internet. Embora não esteja entre as pretensões deste trabalho discorrer de forma pormenorizada sobre sua etimologia, cabe explicar que a palavra meme foi criada pelo biólogo Richard Dawkins (2007) em sua obra O Gene Egoísta, publicada pela primeira vez em 1976. Em sua teoria sobre a evolução cultural, o autor sugere que a transmissão de ideias, hábitos e comportamentos do ser humano é análoga à transmissão genética. À unidade de transmissão cultural ele deu o nome de meme (uma redução da palavra mimeme, que, em grego, significa imitação), para soar como gene. Dawkins considera, de modo controverso às perspectivas sociológicas e antropológicas em relação à cultura, que os comportamentos humanos são baseados em imitações.

\footnotetext{
Exemplos de memes são melodias, ideias, slogans, as modas no vestuário, as maneiras de fazer potes ou de construir arcos. Tal como os genes se propagam no pool gênico saltando de corpo para corpo através dos espermatozoides ou dos óvulos, os memes também se propagam no pool de memes saltando de cérebro para cérebro através de um processo que, num sentido amplo, pode ser chamado de imitação (DAWKINS, 2007, p. 330).
} 
Desde então, o termo sofreu sucessivas reapropriações e ressignificações até que, entre 1990 e 2000, com a popularização dos computadores pessoais e da internet, e, consequentemente, da constituição das primeiras comunidades virtuais, a palavra meme começou a ser usada como sinônimo de "[...] coisas estranhas, legais e bobas na web"4 (STRYKER, 2011, tradução nossa). Assim, entre usuários da internet e integrantes dessas comunidades, meme passou a designar "um tipo de conteúdo digitalmente produzido capaz de sofrer sucessivas reapropriações" (CHAGAS et al., 2017, p. 175).

Nos estudos mais recentes, fica evidente que, apesar de sempre referenciarem o surgimento do termo na obra de Dawkins (2007), os pesquisadores passaram a adotar definições próprias, ligadas ao ambiente digital. Alguns autores (KNOBEL; LANKSHEAR, 2007; SHIFMAN, 2014) procuram diferenciar a definição original da que passou a ser usada na dinâmica da web, utilizando expressões como meme online ou meme de internet. "No discurso vernáculo dos internautas, a tag 'meme de internet' é comumente usada para descrever a propagação de itens como piadas, rumores, vídeos e sites de pessoa para pessoa via internet"5 (SHIFMAN, 2014, p. 2, tradução nossa).

Entretanto, mais importante que uma definição, é preciso compreender e evidenciar o meme em seu aspecto cultural contemporâneo - a cibercultura, definida por Lévy (2010, p. 17) como o "[...] conjunto de técnicas (materiais e intelectuais), de práticas, de atitudes, de modos de pensamento e de valores que se desenvolvem juntamente com o crescimento do ciberespaço”. Em síntese, é a sinergia entre o tecnológico e o social (LEMOS, 2013). Ciberespaço, por sua vez, é o produto da interconexão mundial dos computadores. "O termo especifica não apenas a infraestrutura material da comunicação digital, mas também o universo oceânico de informações que ela abriga, assim como os seres humanos que navegam e alimentam esse universo" (LÉVY, 2010, p. 17).

Para melhor compreender o que é a cibercultura, Lemos (2013) a contrasta com a configuração sociocultural do período histórico anterior, a modernidade. Segundo o autor, a modernidade, fruto do desenvolvimento industrial e tecnológico que marcou a primeira fase do capitalismo, instaurou, a partir da passagem do século XVII para o XVIII, a administração racional da vida social.

\footnotetext{
${ }^{4}[\ldots]$ weird, cool, and silly web stuff.

${ }^{5}$ In the vernacular discourse of netizens, the tag "Internet meme" is commonly applied to describe the propagation of items such as jokes, rumors, videos, and websites from person to person via the Internet.
}

Comun. \& Inf., Goiânia, GO, v. 21, n. 3, p. 150-165, out./dez. 2018. 
A modernidade é a expressão da existência de uma mentalidade técnica, de uma tecnoestrutura e de uma tecnocultura que se enraíza em instituições, incluindo toda a vida social na burocratização, na secularização da religião, no individualismo e na diferenciação institucionalizada das esferas da ciência, da arte e da moral (LEMOS, 2013, p. 62).

Os primeiros sinais de saturação desse modelo aparecem com o desenvolvimento dos meios de comunicação de massa e da sociedade de consumo pós-industrial na segunda metade do século XX. O controle social imposto pelo ideal de evolução para o progresso, encampado por nações em busca de liderança em um mundo cada vez mais global e disputado, passa a ser questionado. Lemos (2013) aponta que esses “sintomas de mal-estar" começam a ser visíveis em manifestações como a contracultura, a revolução verde, a informatização da sociedade, o pós-colonialismo e o pós-industrialismo, que caracterizam o surgimento da ideia de pósmodernidade.

Esse processo foi acompanhado pelo avanço tecnológico, sobretudo da informática, permitindo usos mais individualizados, personalizados, interativos e descentralizados dos meios de comunicação.

O que chamamos de novas tecnologias de comunicação e informação surge a partir de 1975, com a fusão das telecomunicações analógicas com a informática, possibilitando a veiculação, sob um mesmo suporte - o computador -, de diversas formatações de mensagens. Essa revolução digital implica, progressivamente, a passagem do mass media (cujos símbolos são a TV, o rádio, a imprensa, o cinema) para formas individualizadas de produção, difusão e estoque de informação. Aqui a circulação de informações não obedece à hierarquia da árvore (um-todos), e sim à multiplicidade do rizoma (todos-todos) (LEMOS, 2013, p. 69).

Estavam, portanto, lançadas as bases do ciberespaço e, com as práticas sociais decorrentes das novas formas de se comunicar e de se relacionar, da cibercultura. Em síntese, tem-se que a tecnocultura está para a modernidade assim como a cibercultura está para a pósmodernidade, potencializando novos tipos de arranjos sociais e de linguagens, dentre as quais o meme é um representante sintomático.

\section{DIALOGISMO, HETERODISCURSO E CARNAVALIZAÇÃO NOS MEMES DE INTERNET}

O conceito de gênero de discurso de Bakhtin (2016) - um enunciado relativamente estável de determinando campo da comunicação, no qual se relacionam conteúdo temático,

Comun. \& Inf., Goiânia, GO, v. 21, n. 3, p. 150-165, out./dez. 2018. 
estilo e construção composicional - conforma algumas das características do que se denomina meme de internet. Ainda que sejam apresentados de diversas formas, os memes possuem características que o identificam como tais entre os usuários da internet, a exemplo de seu aspecto técnica e esteticamente amador, do bom humor com que são abordados temas diversos e até mesmo de algumas estruturas estilísticas. Em uma obra pioneira sobre o fenômeno, Shifman (2014) chega a delimitar o que chama de "gêneros" de memes, embora compreendase que a autora esteja se referindo mais a tipos de memes que a gêneros entendidos como enunciados estáveis. Nessa tipologia encontram-se, entre outros, os image macros (fotografias com legendas), exploitables (montagens com sobreposição de imagens) e look-alikes (justaposição de retratos de personagens lado a lado para fins de comparação) (TOTH; CHAGAS, 2016), exemplificados na Figura 1.

Figura 1 - Exemplos de memes image macro, exploitable e look-alike

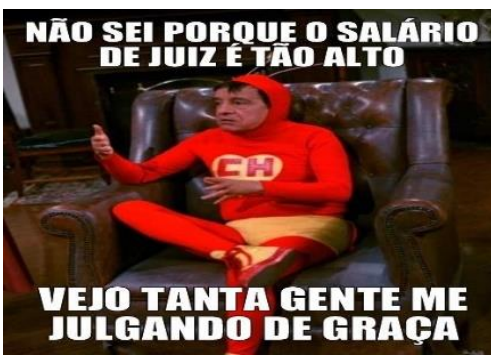

Fonte: Chapolin Sincero $(2018)^{6}$

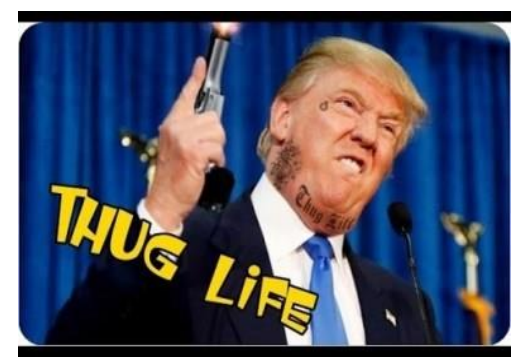

Fonte: Donald Trump Memes (2018) ${ }^{7}$ Fonte: Charges.com $(2015)^{8}$

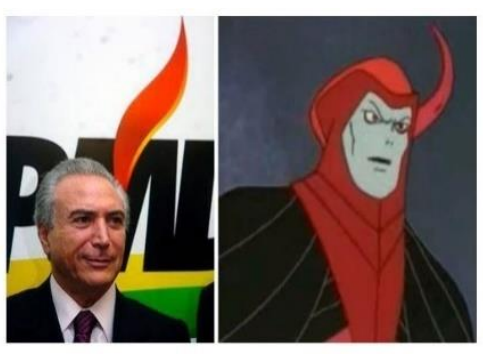

Entretanto, na perspectiva bakhtiniana de gênero, o meme é mais bem compreendido como um "elo na cadeia da comunicação discursiva" (BAKHTIN, 2016, p. 57), da qual é sua unidade real. Tal concepção, que perpassa toda a construção do pensamento do referido autor, contrapõe-se aos estudos da língua como sistema, como se a ela fosse possível aplicar uma técnica laboratorial de separação, decantação e análise. Ao contrário, Bakhtin imprime um caráter muito mais dinâmico às possibilidades de utilização da linguagem, na medida em que os discursos não têm início nem fim definidos. Como explica Machado (2005), o gênero é definido por sua existência cultural, eliminando o nascimento original e a morte definitiva. Emergem, pois, as noções de dialogismo e de responsividade, que colocam quem fala e quem escuta em um processo de intercâmbio mútuo.

\footnotetext{
${ }^{6}$ Disponível em: <https://www.facebook.com/ChapolinSincero>. Acesso em: 10 jul. 2018.

${ }^{7}$ Disponível em: <https://chiefdonaldtrump.com/donald-trump-memes/>. Acesso em: 10 jul. 2018.

${ }^{8}$ Disponível em: <https://charges.uol.com.br/emails-comentados/2015/02/26/vingadores〉. Acesso em: 10 jul. 2018.
}

Comun. \& Inf., Goiânia, GO, v. 21, n. 3, p. 150-165, out./dez. 2018. 
De fato, o ouvinte, ao perceber e compreender o significado (linguístico) do discurso, ocupa simultaneamente em relação a ele uma ativa posição responsiva: concorda ou discorda dele (total ou parcialmente), completa-o, aplica-o, prepara-se para usá-lo, etc.; essa posição responsiva do ouvinte se forma ao longo de todo o processo de audição e compreensão desde o seu início, às vezes literalmente a partir da primeira palavra do falante. Toda compreensão da fala viva, do enunciado vivo é de natureza ativamente responsiva (BAKHTIN, 2016, p. 24-25).

Essa percepção converge com o atual paradigma dos estudos da Comunicação. A visão linear e puramente esquemática dos processos comunicacionais que partem do pressuposto de um sujeito reificado e, por isso mesmo, passivo e acrítico (SOUSA, 1995), tem dado lugar a abordagens teóricas que relocalizam o receptor e demonstram sua capacidade de apropriação e ressignificação das mensagens, sobretudo em meio ao ambiente das novas tecnologias de informação e comunicação. O modelo emissor - mensagem - receptor tem sido superado na medida em que o público também passa a produzir e distribuir conteúdo, valendo-se das bases técnicas e materiais que impulsionam esse processo.

Traços dessa dinâmica foram identificados por Jenkins (2009) ao estudar as produções culturais e as interações sociais de comunidades de fãs que, segundo ele, foram as primeiras a se apropriar criativamente das mídias emergentes na virada do milênio, agora já bastante consolidadas e em constante transformação. O autor afasta a ideia de um determinismo tecnológico, embora argumente que relações offline foram e são potencializadas e/ou transformadas com as ferramentas digitais. Nas formas de comunicação midiatizadas, essa nova dinâmica se insere no que ele denomina cultura da participação.

Essa mudança - de distribuição para circulação - sinaliza um movimento na direção de um modelo mais participativo de cultura, em que o público não é mais visto como simplesmente um grupo de consumidores de mensagens préconstruídas, mas como pessoas que estão moldando, compartilhando, reconfigurando e remixando conteúdos de mídia de maneiras que não poderiam ter sido imaginas antes (JENKINS; FORD; GREEN, 2014, p. 24).

Moldar, compartilhar, reconfigurar e remixar estão no cerne do que hoje se entende por meme de internet. Mesmo os mais básicos programas de edição de imagem, instalados em computadores pessoais ou disponíveis em aplicativos de celular, permitem fazer montagens rápidas que, em poucos minutos, já estão circulando pelos sites de redes sociais. Afirma Lévy (2010, p. 153) "Na cibercultura, qualquer imagem é potencialmente matéria-prima de uma outra imagem, todo texto pode constituir o fragmento de um texto ainda maior [...]". Trata-se de conteúdo paradoxalmente original, às margens dos veículos de comunicação (e que às vezes até Comun. \& Inf., Goiânia, GO, v. 21, n. 3, p. 150-165, out./dez. 2018. 
pautam a mídia tradicional). São mensagens que, como explicam Jenkins, Ford e Green (2014), ora circulam em seus nichos, ora invadem o mainstream, influenciando campanhas publicitárias, produtos da indústria cultural, disputas políticas e ativismos de todo o tipo.

Se Machado (2005, p. 154) considera que Bakhtin iluminou um processo de "prosificação da cultura letrada", altamente transgressor e de desestabilização de uma ordem cultural que parecia inabalável, por que não considerar que vivemos atualmente uma "memetização" cultural, que desafia a etiqueta digital e o "bom gosto" de um humor higienizado? Hoje, "ciberhumoristas" anônimos inundam a web com suas criações perspicazes e visualmente mal-acabadas, reconfigurando significativamente a linguagem e as formas de leitura, de compreensão e de consumo do humor contemporâneo.

Voltando às categorias bakhtinianas, não seria exagero dizer que as novas tecnologias potencializam as formas e as possibilidades de responsividade. Além disso, com as variadas ferramentas interativas, a "alternância dos sujeitos no discurso" - uma das peculiaridades do enunciado, segundo Bakhtin (2016) - se dá de uma forma frenética nos meios digitais de comunicação, a exemplo de publicações em comunidades virtuais que recebem milhares de comentários em poucos minutos. O sentido, aliás, é construído nessas idas e vindas de textos, fotos e vídeos continuamente alterados e adaptados que caracterizam o meme de internet. A essa construção coletiva de sentido, Shifman (2014, p. 30, tradução nossa) dá o nome de lógica hipermemética: "memes estão presentes nas esferas pública e privada não como entidades esporádicas, mas como enormes grupos de textos e imagens"9.

Outra dimensão que pode ser aventada em uma leitura atenta do meme de internet é a do heterodiscurso, sobre o qual Bakhtin (2015) discorre em sua teoria do romance. Explica o russo que o romance, como um todo verbalizado, é um fenômeno pluriestilístico, heterovocal e dissonante, que contém e provoca um diálogo social das linguagens. Em síntese, é um heterodiscurso dialogizado.

Para Bakhtin, o heterodiscurso é produto da estratificação interna de uma língua nacional única em dialetos sociais, falares de grupos, jargões profissionais, e compreende toda a diversidade de vozes e discursos que povoam a vida social, divergindo aqui, contrapondo-se ali, combinando-se adiante, relativizando-se uns aos outros e cada uma procurando seu próprio espaço de realização. O resultado de tudo isso é um mundo povoado por um heterodiscurso oriundo das linguagens das gerações e das faixas etárias, das tendências e dos partidos, das autoridades, dos círculos e das modas

\footnotetext{
${ }^{9}$ Memes are present in the public and private sphere not as sporadic entities but as monstrously sized groups of texts and images.
}

Comun. \& Inf., Goiânia, GO, v. 21, n. 3, p. 150-165, out./dez. 2018. 
passageiras, dos dias sociopolíticos e até das horas, em suma, de todas as manifestações da experiência humana individual e social e da vida das ideias (BEZERRA, 2015, p. 13).

Esse conceito é elaborado a partir da crítica à filosofia da linguagem, à linguística e à estilística, que, segundo Bakhtin (2015), postulam uma relação monológica entre o falante e sua língua, que se opõe ao heterodiscurso. Daí advêm, por exemplo, as normas linguísticas que criam artificialmente núcleos estáveis de uma língua oficialmente reconhecida como a correta. Mas o autor vai além do aspecto linguístico ao afirmar que esse processo guarda relação direta com a centralização sociopolítica e cultural - perspectiva que se mostra reveladora tendo em vista que Bakhtin elabora grande parte de sua teoria no intervalo das duas grandes guerras mundiais e durante seu exílio no Cazaquistão durante o regime stalinista na então União Soviética (BEZERRA, 2015).

Construídos com uma gramática propositalmente avessa à norma culta da língua, valorizando e exagerando regionalismos e vícios de linguagem, apreende-se que os memes são terreno fértil para o heterodiscurso, "[...] paródica e polemicamente afiado contra as linguagens oficiais da contemporaneidade" (BAKHTIN, 2015, p. 43). Em última instância, acabam se constituindo, por si só, como uma "língua digital", a exemplo dos GIFs ${ }^{10}$ utilizados para expressar reações e sentimentos. É nesse sentido que os memes integram a força centrífuga da língua, que, segundo Bakhtin (2015), vai de encontro à centralização verboideológica e à unificação, provocando descentralização e separação.

Por causa do teor bem-humorado dos memes de internet, a carnavalização também parece ser-lhes um conceito intrínseco. Porém, ao discorrer sobre a concepção carnavalesca do mundo na Idade Média e no Renascimento, Bakhtin (2002) vai muito além do aspecto meramente cômico, enfatizando a essência popular do riso e o caráter de ruptura em relação à ordem e às normas sociais.

$\mathrm{O}$ mundo infinito das formas e manifestações do riso opunha-se à cultura oficial, ao tom sério, religioso e feudal da época. Dentro da sua diversidade, essas formas e manifestações - as festas públicas carnavalescas, os ritos e cultos cômicos especiais, os bufões e tolos, gigantes, anões e monstros, palhaços de diversos estilos e categorias, a literatura paródica, vasta e multiforme, etc. - possuem uma unidade de estilo e constituem partes e parcelas da cultura cômica popular, principalmente da cultura carnavalesca, una e indivisível (BAKHTIN, 2002, p. 4).

\footnotetext{
${ }^{10}$ Imagens curtas em movimento, geralmente com um personagem desempenhando uma ação ou uma expressão facial.
}

Comun. \& Inf., Goiânia, GO, v. 21, n. 3, p. 150-165, out./dez. 2018. 
O pensador russo percorre as manifestações do humor em três categorias: os ritos e espetáculos carnavalescos, as obras cômicas verbais e o vocabulário grosseiro. As festas populares, que podiam durar até três meses, instituíam uma espécie de "segundo mundo" ou "mundo ao revés" - exterior à igreja e ao estado -, sem palco e sem fronteiras. A eliminação provisória das relações hierárquicas também fez surgir uma "linguagem carnavalesca típica", da qual sobressai o riso festivo, compartilhado por todos. "[...] o mundo inteiro parece cômico e é percebido e considerado no seu aspecto jocoso, no seu alegre relativismo" (BAKHTIN, 2002, p. 10).

Em relação às obras cômicas, Bakhtin destaca a disseminação de uma literatura paródica e recreativa. No vocabulário, também predominava o traço de liberdade, com expressões proibidas na comunicação oficial. O autor explica que até as grosserias e os palavrões, naturalmente degradantes, continham um aspecto de regeneração e renovação, contribuindo para a criação de uma atmosfera de liberdade. Esse caráter ordinariamente transgressor converge com o que apregoam os entusiastas teóricos da cibercultura (LEMOS, 2013; LÉVY, 2010) e da cultura participativa (JENKINS, 2009). Os dois primeiros autores identificam e descrevem uma série de práticas sociais, novas ou reformuladas, que flertam com a contestação, inseridas na dinâmica de um mundo permeado pelas novas tecnologias, e que vão da moda à arte, da música aos games.

Os exemplos são numerosos: o neopaganismo dos zippies, o faça você mesmo dos cyberpunks, a criptografia cara aos cypherpunks, o ativismo dos hackers e a violência dos crackers, os fanáticos dos jogos eletrônicos, o isolamento dos otakus japoneses, os delírios das raves e da realidade virtual, a arte eletrônica, a moda sintética ou cyberfashion, os transumanistas extropians... (LEMOS, 2013, p. 19).

Nessa perspectiva, o meme de internet chega a tangenciar o grotesco, como sistema de imagens da cultura cômica popular (BAKHTIN, 2002), dado seu incentivo à invenção e à associação de elementos heterogêneos. Esteticamente, floresce o caricatural e o paródico, com formas exageradas e sem proporções. Por não exigir um domínio técnico especializado dos programas de edição de imagens, o meme é deliberadamente construído com formas toscas, a exemplo das publicações da página Goiânia Mil Grau, que terá um de seus vídeos analisados na próxima seção. 


\section{GOIÂNIA MIL GRAU}

Criada no início de 2013 como uma página de humor e entretenimento no Facebook ${ }^{11}$, a Goiânia Mil Grau é gerenciada por dois jovens amigos que justificam seu surgimento pela necessidade de alimentar o orgulho de ser goiano nas redes sociais. Suas publicações, feitas por meio de montagens e paródias típicas dos memes de internet, fazem referência bem-humorada a aspectos culturais do goiano e do goianiense. Nelas são tratados temas diversos, como os hábitos alimentares (da pamonha ao pequi) ${ }^{12}$, as gírias e o linguajar regionais ("cê tá bão?", “que paia!") ${ }^{13}$, a má conduta do motorista nas ruas da cidade, os personagens midiáticos (como os apresentadores dos telejornais locais) e os figurões da política (o atual prefeito de Goiânia, Iris Rezende, um octogenário veterano da política local, é um dos "alvos" recorrentes das piadas). Além da página no Facebook - que possui o maior alcance, com mais de 219 mil seguidores ${ }^{14}$-, os idealizadores da Goiânia Mil Grau mantêm perfis no Twitter, no Instagram, no YouTube e um website.

Para além das piadas autorreferentes, muitos memes publicados pela Goiânia Mil Grau trazem críticas aos problemas da cidade, como a violência, a situação precária do transporte público e as obras de infraestrutura paralisadas. Um dos exemplos é o vídeo Me robaro no Eixon (Me roubaram no Eixão) ${ }^{15}$. A Figura 2 mostra algumas imagens que compõem a paródia.

Figura 2 - Imagens do vídeo Me robaro no Eixon
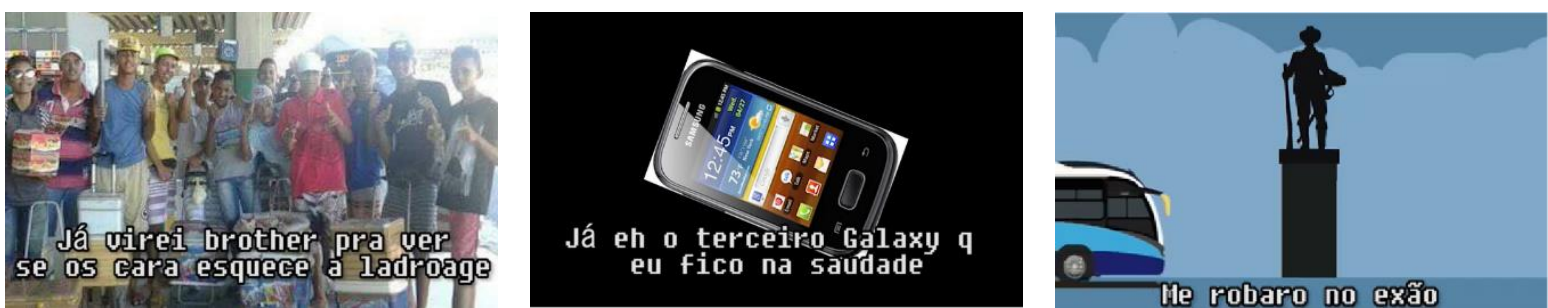

Fonte: Goiânia Mil Grau (2018) ${ }^{12}$.

\footnotetext{
${ }^{11}$ Disponível em: <https://www.facebook.com/goianiamilgrauoficial/>. Acesso em: 16 jul. 2018.

${ }^{12}$ Embora não chegue a ser um prato exclusivamente goiano, a pamonha é associada aos hábitos culinários do estado por conta da grande quantidade de estabelecimentos que têm a iguaria como carro-chefe - as famosas pamonharias. Já o pequi, por ser um fruto típico do Cerrado (bioma que se estende pela quase totalidade do território goiano), guarda relação direta com o estado e sua culinária. Trata-se de um fruto cujo caroço amarelo tem um sabor marcante, podendo ser consumido puro ou com arroz e frango. Como o pequi possui espinhos em seu interior, para comê-lo é preciso roer o caroço.

${ }^{13}$ As frases fazem referência à supressão de sílabas do linguajar coloquial e a termos típicos do que configuraria o "goianês". "Cê tá bão?" é uma redução do cumprimento "Você está bem?" e "Que paia!" é uma gíria usada para expressar sentimentos de decepção ou descontentamento, como "Que ruim!" ou "Que chato!".

${ }^{14}$ Atualizado em 10 de julho de 2018.

${ }^{15}$ Disponível em: < https://www.facebook.com/goianiamilgrauoficial/videos/1494953607269528/>. Acesso em: 10 jul. 2018.
}

Comun. \& Inf., Goiânia, GO, v. 21, n. 3, p. 150-165, out./dez. 2018. 
O vídeo é uma paródia do clipe da música Californication, lançada em 2000 pela banda norte-americana Red Hot Chili Peppers, no álbum de mesmo nome ${ }^{16}$. A canção é uma crítica ao estilo de vida californiano e ao sonho de sucesso de Hollywood, com a imposição de padrões culturais e estéticos. No caso da Goiânia Mil Grau, o vídeo aborda a falta de segurança nos ônibus do Eixo Anhanguera - uma das linhas mais movimentadas do transporte coletivo, que liga a Região Metropolitana de Goiânia de leste a oeste. Por ela circulam ônibus articulados e biarticulados, chamados pelos usuários do transporte coletivo de Eixão.

A partir das categorias bakhtinianas, destaca-se inicialmente o elemento intertextual (FIORIN, 2006), evidente na utilização da melodia original e da sequência de imagens similares ao clipe. No caso da letra parodiada, o aspecto cômico é ressaltado com o que Saliba (2002) chama de macarronismo do idioma, uma espécie de "deformação da língua", como quando o sufixo inglês “-tion” (“-ão") é "traduzido" literalmente para o português, gerando palavras como "enganeixon" e "informeixon". A essência paródica também ressalta o aspecto carnavalizado do vídeo, potencializado por uma letra debochada e irônica.

Já a dimensão cultural e heterogênea do discurso de que fala Bakhtin está refletida nos aspectos da cultura goiana e goianiense evidenciados ao longo do vídeo. Do modo típico de falar da população, enfatiza-se a falta de concordância verbal e nominal e o uso contraído do diminutivo (radinho vira "radim") e de palavras como "nóis" e "roubaro". Em relação aos costumes, logo no início uma pipa no céu é descrita como "raia torada", numa referência às disputas com as linhas de cerol, feitas com mistura de cola e caco de vidro, nas quais o objetivo é cortar (torar) outas linhas. Já no fim do vídeo, é representado um vendedor oferecendo "5 paçocas por 1 real”, em uma alusão aos vendedores ambulantes que, à margem da lei, estão presentes nos terminais e dentro dos próprios ônibus.

Também são vários os discursos que atravessam o vídeo, provocando a compreensão e a identificação que um enunciado, na perspectiva bakhtiniana, oferece. Um deles é a construção discursiva do ladrão, caracterizado por adolescentes ("e o menó levou até meu fone") que usam determinada vestimenta (“e quando eu vejo um Quik ${ }^{17}$ eu penso 'os caras não me deixam"”) e que são reincidentes no crime (imagem de uma tornozeleira eletrônica). Na maioria das imagens utilizadas na paródia, a figura do criminoso é representada por adolescentes e jovens negros. Vale lembrar que essa caracterização também passa pelo discurso midiático, sobretudo dos

\footnotetext{
${ }^{16}$ Disponível em: <https://www.youtube.com/watch?v=YlUKcNNmywk>. Acesso em: 10 jul. 2018.

${ }^{17}$ Referência à marca Quiksilver, cujos produtos, sobretudo os bonés, são alvo de falsificações vendidas em feiras populares.
}

Comun. \& Inf., Goiânia, GO, v. 21, n. 3, p. 150-165, out./dez. 2018. 
口留

telejornais populares, que expõem diariamente infratores menores de idade (os “de menor") em suas reportagens.

Outro discurso construído é o das classes média e baixa, que constituem a grande parcela da população que depende de um transporte coletivo de péssima qualidade e, por isso, está suscetível à violência. Tal problema é retratado pelas imagens de terminais e ônibus superlotados e sem o mínimo conforto. A esse "estilo de vida" são acrescentadas características como a utilização do crediário para a aquisição de um bem, como no caso do telefone celular (“meu pai nem pagou, nóis parcelou”). Já outros elementos secundários revelam construções discursivas que ultrapassam os limites regionais, como fazer referência à corrupção utilizando a foto de um político colocando dinheiro na cueca, no trecho "eu tento esconder na cueca para que não vejam", e a traição conjugal evidenciada na parte que diz que, apesar da compra de um celular novo, o antigo foi preservado para "metê os enganeixon".

É certo que, para a atribuição de sentido ao vídeo, o contexto é determinante, embora discursivamente a paródia é bem-sucedida ao revelar que o problema da falta de segurança é tão crítico que ser roubado no Eixo Anhanguera acaba sendo uma situação comum, da qual fatalmente é ou será vítima quem utiliza a linha. A responsividade de quem assiste ao vídeo integra esse sentido e, por uma especificidade das novas tecnologias digitais, se materializa quase que instantaneamente com os recursos que permitem fazer comentários e compartilhar o conteúdo para outras pessoas. É o lugar propício para externar o excedente de visão (BAKHTIN, 2011), condicionado pela singularidade e pela insubstitutibilidade do lugar de cada um no mundo. No caso analisado, a paródia foi vista 137 mil vezes, foi curtida por mais de 5 mil pessoas e teve 4 mil compartilhamentos e comentários. Nestes últimos, não faltaram relatos pessoais de quem foi vítima de crimes no Eixão, além da enumeração de outros problemas relacionados à linha e críticas à inação do poder público.

\section{CONSIDERAÇÕES FINAIS}

É fato que as contribuições de Mikhail Bakhtin não se restringem ao estudo da literatura. Ao se dedicar à tradução das obras deste pensador para a língua portuguesa, Bezerra (2015) considera que o conjunto de categorias e de conceitos bakhitinianos compõem um sistema de reflexões que talvez possa ser chamado de filosofia estética. Isso fica evidente quando, na leitura dessas reflexões, tem-se a sensação de que elas parecem não se referir especificamente ao campo da literatura e do romance, mas sim à existência humana em seu aspecto volitivo- 
emocional, dos elementos mais elementares da vida cotidiana à complexidade das relações, em última instância, do "existir-evento" de cada um de nós (BAKHTIN, 2010).

O que se pretendeu aqui foi tirar proveito dessa amplitude teórica e usá-la como lente para enxergar um fenômeno da atualidade. Até porque, como lembra Machado (2005, p. 163), "ainda que o objeto privilegiado nos estudos de Bakhtin tenha sido o romance, o alvo de seu interesse teórico eram as formações da prosa na vida cotidiana com todas as suas imperfeições, não acabamentos, efemeridade e aspectos grotescos". É nesse sentido que as reflexões se convertem em possibilidade metodológica, sendo aqui operacionalizada para a análise de um vídeo permeado por construções discursivas sobre o que é ser goiano e goianiense.

Da análise empreendida, pode-se inferir que, inserido na dinâmica das novas tecnologias de comunicação, o meme de internet, com sua típica retórica do humor, é capaz de articular elementos diversos - de aspectos regionais de uma cidade e de um estado a temáticas densas como a ineficiência do poder público, a violência, a corrupção e a desigualdade social. Dessa forma, são acionados efeitos de significação relacionados à noção de identidade e pertencimento, abrindo também espaço para a crítica social. Tudo isso, no caso do vídeo em questão, valendo-se das "múltiplas vozes" às quais faz referência a categoria bakhitiniana do heterodiscurso, tanto do ponto de vista da multiplicidade mesma de discursos quanto em suas especificidades estilísticas, da qual a exaltação do linguajar "goianês" é uma das mais evidentes.

Além disso, ao romper com o discurso burocrático que conforma cidadãos em um cotidiano de injustiça social que impõe obstáculos ao exercício do básico direito de ir e vir na cidade, a paródia carnavaliza o status quo. Com a ironia que lhe é peculiar, a página Goiânia Mil Grau expõe graves problemas enfrentados pela população, ao mesmo tempo em que justifica seu surgimento a partir da necessidade de alimentar o "orgulho de ser goiano".

Por fim, é importante mencionar que os cenários fantasiados da Goiânia Mil Grau nem sempre estão presos a universos cômicos específicos, mas abrem, em termos bakhitinianos, possibilidades dialógicas para diferentes horizontes espaciais, que congregam o hibridismo entre o local, o nacional e o global, além de criar vínculos multitemporais. A sustentação desse emaranhado de sentidos que vasculha símbolos de realidades específicas se dá pela intensa recorrência à participação ativa do internauta, tanto na produção de significados quanto por meio das ferramentas de interação das novas tecnologias, o que explica em parte o sucesso da página. 


\section{REFERÊNCIAS}

BAKHTIN, Mikhail. A cultura popular na Idade Média e no Renascimento: o contexto de François Rebelais. 5 ed. Tradução de Y. F. Vieira. São Paulo: Annablume; São Paulo: Hucitec, 2002.

Estética da criação verbal. 6. ed. São Paulo: WMF Martins Fontes, 2011.

Os gêneros do discurso. Organização, tradução, posfácio, notas e glossário de P. Bezerra; notas da edição russa de S. Botcharov. São Paulo: Editora 34, 2016.

Para uma filosofia do ato responsável. Tradução aos cuidados de V. Miotello e C. A. Faraco. São Carlos: Pedro e João, 2010.

Teoria do romance I: a estilística. Tradução, prefácio, notas e glossário de P. Bezerra; organização da edição russa de S. Botcharov e Vadim Kójinov. São Paulo: Ed. 34, 2015.

BEZERRA, Paulo. Prefácio. In: BAKHTIN, Mikhail. Teoria do romance I: a estilística. Tradução, prefácio, notas e glossário de P. Bezerra; organização da edição russa de S. Botcharov e Vadim Kójinov. São Paulo: Ed. 34, 2015.

CHAGAS et al. A política dos memes e os memes da política: proposta metodológica de análise de conteúdo dos memes dos debates eleitorais de 2014. Intexto, Porto Alegre, n. 38, p. 173-196, jan./abr. 2017. Quadrimestral. Disponível em: 〈https://goo.gl/4dsmDK〉. Acesso em: 13 ago. 2017.

DAWKINS, Richard. O gene egoísta. São Paulo: Companhia das Letras, 2007.

FIORIN, José Luiz. Interdiscursividade e intertextualidade. In: BRAIT, Beth (Org.). Bakhtin: outros conceitos-chave. São Paulo: Contexto, 2006.

JENKINS, Henry. Cultura da convergência. 2 ed. São Paulo: Aleph, 2009.

; FORD, Sam; GREEN, Joshua. Cultura da conexão: criando valor e significado por meio da mídia propagável. São Paulo: Aleph, 2014.

KNOBEL, Michele; LANKSHEAR, Colin. Online memes, affinities, and cultural production. In: A new literacies sampler. [S.1]: Peter Lang, 2007. p.199-227.Disponível em: $<$ https://www.researchgate.net/publication/283968435_Online_memes_affinities_and_cultura 1_production>. Acesso em: 13 jul. 2017.

LEMOS, André. Cibercultura: tecnologia e vida social na cultura contemporânea. 6 ed. Porto Alegre: Sulina, 2013.

LÉVY, Pierre. Cibercultura. 3 ed. São Paulo: Editora 34, 2010.

MACHADO, Irene. Gêneros discursivos. In: BRAIT, Beth (Org.). Bakhtin: conceitos-chave. São Paulo: Contexto, 2005. 
SALIBA, Elias Thomé. Raízes do riso: a representação humorística na história brasileira: da Belle Époque aos primeiros tempos do rádio. São Paulo: Companhia das Letras, 2002.

SHIFMAN, Limor. Memes in digital culture. Cambridge: MIT Press, 2014.

SOUSA, Mauro Wilton de. Recepção e comunicação: a busca do sujeito. In: (Org.). Sujeito: o lado oculto do receptor. São Paulo: Brasiliense, 1995.

SOUZA JÚNIOR, Jaime de. "\#In Brazilian Portuguese”, memes e fenômenos: linguística e as sugestões para reconhecer e investigar eventos digitais. In: Anais do Encontro Virtual de Documentação em Software Livre e Congresso Internacional de Linguagem e Tecnologia Online, Belo Horizonte, v. 4, n. 1, 2015. Disponível em: $<$ http://www.periodicos.letras.ufmg.br/index.php/anais_linguagem_tecnologia/issue/view/459 >. Acesso em: 15 jan. 2018.

STRYKER, Cole. Epic win for anonymous: how 4chan'n army conquered the web. Nova York: The Overlook Press, 2011. Disponível em: <https://100vampirenovels.com/pdfnovels/epic-win-for-anonymous-by-stryker-cole-free>. Acesso em: 11 nov. 2017.

TOTH, Janderson; CHAGAS, Viktor. Monitorando memes em mídias sociais. In: SILVA, Tarcísio; STABILE, Max (Org.). Monitoramento e pesquisa em mídias sociais: metodologias, aplicações e inovações. São Paulo: Uva Limão, 2016. 